\title{
Enzymes of the Mandelate Pathway in Bacterium N.C.I.B. 8250
}

\author{
By S. I. T. KENNEDY* AND C. A. FEWSON \\ Department of Biochemistry, University of Glasgow
}

(Received 23 October 1967)

\begin{abstract}
1. Bacterium N.C.I.B. 8250 was grown on DL-mandelate, benzyl alcohol, benzoylformate, benzaldehyde and benzoate and also on 2-hydroxy, 4-hydroxy, 3,4-dihydroxy and 4-hydroxy-3-methoxy analogues of these compounds. The enzymic complements of the cells were determined and the specificities of some of the enzymes examined. 2. Growth on mandelate or benzoylformate induces Lmandelate dehydrogenase, benzoylformate decarboxylase, benzyl alcohol dehydrogenase and a heat-stable as well as a heat-labile benzaldehyde dehydrogenase. Growth on benzyl alcohol or benzaldehyde induces benzyl alcohol dehydrogenase and the heat-labile benzaldehyde dehydrogenase. 3. The enzymes of the mandelateto-benzoate pathway are non-specifically active on, and induced by, all the substituted analogues that support growth. 4. Benzoate oxidase is induced by growth on benzoate or on 2-hydroxybenzoate. 2-Hydroxybenzoate hydroxylase, 4-hydroxybenzoate hydroxylase and 4-hydroxy-3-methoxybenzoate $O$-demethylase are induced only by growth on homologous substrates. 5. The results of the investigation are discussed with regard to the possible regulation of the enzyme systerns.
\end{abstract}

Bacterium N.C.I.B. 8250 (formerly known as 'Vibrio O 1'; Sebald \& Véron, 1963; Véron, 1966; Fewson, 1967b) can utilize L-mandelate, benzoylformate, benzyl alcohol, benzaldehyde or benzoate as sole sources of carbon and energy for growth. The organism can also grow on the 2-hydroxy, 4-hydroxy, 3,4-dihydroxy and 4-hydroxy-3methoxy derivatives of these compounds (Fewson, 1967a). The pathways of oxidation have been determined by the technique of simultaneous adaptation and the side chains of each of the L-mandelates or benzyl alcohols found to be oxidized to the corresponding benzoates (Kennedy \& Fewson, 1966):

$$
\begin{aligned}
& \text { L-Mandelate } \rightarrow \text { benzoylformate } \rightarrow \\
& \text { benzaldehyde } \rightarrow \text { benzoate } \\
& \text { Benzyl alcohol } \rightarrow \text { benzaldehyde } \rightarrow \text { benzoate }
\end{aligned}
$$

The patterns of oxygen uptake with whole cells indicated that benzoate and 2-hydroxybenzoate are oxidized to catechol and that 4-hydroxybenzoate and 4-hydroxy-3-methoxybenzoate are converted into 3,4-dihydroxybenzoate. Catechol and 3,4dihydroxybenzoate undergo ring cleavage to give, ultimately, $\beta$-oxoadipate (Cain, 1961 ; Ornston \& Stanier, 1964).

The present investigation, part of which has been published in a preliminary form (Fewson \&

* Present address: Department of Microbiology, University of Reading.
Kennedy, 1968), deals in more detail with the substrate and induction specificity of some of the enzymes involved in this pathway. This work was undertaken because most previous studies on the oxidation of mandelate have been done with Pseudomonas spp., which differ in many important respects (e.g. Cánovas, Ornston \& Stanier, 1967) from the Moraxella-Acinetobacter group of bacteria to which bacterium N.C.I.B. 8250 belongs (Véron, 1966; Fewson, 1967b). Cánovas et al. (1967) and Cánovas \& Stanier (1967) have already demonstrated that Moraxella calcoacetica (strain 73, which does not utilize mandelate for growth; Professor $\mathbf{M}$. Doudoroff, personal communication) and a number of species of Pseudomonas metabolize catecho! and 3,4-dihydroxybenzoate through the same irtermediates, but that the patterns of enzyme induction are quite different in the two types of organism.

\section{METHODS AND MATERIALS}

Organisms. Bacterium N.C.I.B. 8250 (Achromobacter sp.) was obtained from the National Collection of Industrial Bacteria, Torry Research Station, Aberdeen. Stock cultures were maintained in Oxoid cooked-meat medium stored at $4^{\circ}$. Subcultures were made into Oxoid nutrient broth at intervals of about 2 months and were also kept at $4^{c}$. Inocula used in the various experiments were produced immediately before use by a further subculture $[0 \cdot 1 \%(\mathrm{v} / \mathrm{v})$ inoculum] into $100 \mathrm{ml}$. quantities of nutrient broth contained in $500 \mathrm{ml}$. Erlenmeyer flasks and incubated without shaking for $24 \mathrm{hr}$. at $30^{\circ}$. 
Three strains of Gram-negative organisms, B9, $\beta 8$ and M2, known to possess catechol 2,3-oxygenase (Pankhurst, 1965), were obtained from Miss E. S. Pankhurst (Gas Council London Research Station, London, S.W. 6) and maintained by monthly subculture on Oxoid nutrient agar.

Media. The standard basal medium contained $2 \mathrm{~g}$. of $\mathrm{KH}_{2} \mathrm{PO}_{4}$ and $1 \mathrm{~g}$. of $\left(\mathrm{NH}_{4}\right)_{2} \mathrm{SO}_{4}$ in 11 . of glass-distilled water adjusted to $\mathrm{pH} 7 \cdot 0$ with $\mathrm{NaOH}$ (Fewson, 1967a). Carbon sources were usually dissolved in this basal medium before adjustment of the $\mathrm{pH}$, and then sterilized by autoclaving at $109^{\circ}$. Benzyl alcohol, benzaldehyde, 2-hydroxy-DLmandelate, 2-hydroxybenzoylformate, 2-hydroxybenzaldehyde, 4 - hydroxy - DL - mandelate, 3,4 - dihydroxy - DL mandelate, 3,4-dihydroxybenzaldehyde, 3,4-dihydroxybenzoate, 4-hydroxy-3-methoxy-DL-mandelate, 4-hydroxy3-methoxybenzyl alcohol, 4-hydroxy-3-methoxybenzaldehyde and 4-hydroxy-3-methoxybenzoate, because they are heat-labile or volatile, were dissolved in glass-distilled water, adjusted to $\mathrm{pH} 7 \cdot 0$, and sterilized by filtration through Millipore filters (GSWP04700, $0 \cdot 22 \mu$ ) before their aseptic addition to suitable concentrations of sterile basal medium. Immediately before inoculation $2 \%(\mathrm{w} / \mathrm{v}) \mathrm{MgSO}_{4}, 7 \mathrm{H}_{2} \mathrm{O}$ $(20 \mathrm{ml}$./1. of medium) was added.

Strains B9, $\beta 8$ and M2 were grown in a medium (Miss E. S. Pankhurst, personal communication) that contained (per 1 . of glass-distilled water): $\mathrm{NaNO}_{3}, 2 \mathrm{~g}$; $\mathrm{KH}_{2} \mathrm{PO}_{4}, 1 \mathrm{~g}$.; $\mathrm{MgSO}_{4}, 7 \mathrm{H}_{2} \mathrm{O}, 0.4 \mathrm{~g} . ; \mathrm{KCl}, 0.5 \mathrm{~g}$; $\mathrm{FeSO}_{4}, 7 \mathrm{H}_{2} \mathrm{O}, 0.01 \mathrm{~g}$.; phenol, $0 \cdot 25 \mathrm{~g}$. The $\mathrm{pH}$ was adjusted to $\mathbf{7 \cdot 2}$. There was a slight precipitate sfter autoclaving at $109^{\circ}$.

Batch cultures. Bacterium N.C.I.B. 8250 was grown at $30^{\circ}$ in 21. quantities of medium contained in 31. flat-bottomed Pyrex flasks plugged with non-absorbent cotton wool; larger quantities were grown occasionally (e.g. 81. in 101 . flasks) when greater amounts of cells were required. The carbon source was present at a final concentration of $1 \mathrm{~mm}$, except that 2-hydroxybenzaldehyde, because of problems of toxicity, was provided at $0.2 \mathrm{~mm}$. DL-Mandelate and the substituted mandelates were provided at $2 \mathrm{~mm}$ to give $1 \mathrm{~mm}$ concentrations of the L-isomers. The inocula $(5 \%, v / v)$ were preadapted by growth on the same carbon source as was to be used in the batch culture. For this purpose $100 \mathrm{ml}$. quantities of media contained in $250 \mathrm{ml}$. Erlenmeyer flasks were inculated $(0 \cdot 2 \%, \mathrm{v} / \mathrm{v})$ with a $24 \mathrm{hr}$. nutrient-broth culture and grown into the early stationary phase on a rotary shaker (Mk. V; L. H. Engineering Co., Bells Hill, Stoke Poges, Bucks.) moving through a stroke of 1 in. at about 180 oscillations/min. After inoculation, large-scale cultures were grown under conditions of vigorous aeration in the apparatus described by Harvey, Fewson \& Holms (1968). Growth was followed by taking $4 \mathrm{ml}$. samples at intervals and measuring the $E_{500}$ values in a Spectronic 20 colorimeter with standard tubes of internal diam. $11 \cdot 7 \mathrm{~mm}$. Growth was stopped during the penultimate generation by surrounding the flasks with ice. The cells were kept cool until all had been harvested by batch centrifugation at $12000 \mathrm{~g}$ for $30 \mathrm{~min}$. at $4^{\circ}$ and washed once with the medium that was to be used subsequently for suspension. Experiments in the Warburg apparatus with washed-cell suspensions were invariably started within $4 \mathrm{hr}$. of harvesting. Cell-free extracts were usually prepared at once, but Jccasionally cells were stored at $-50^{\circ}$.

Ultrasonic disruption. A suitable volume (20-40 ml.) of a washed-cell suspension $(50 \mathrm{mg} . / \mathrm{ml}$.) was placed in a coneshaped glass vessel equipped with four cooling vanes and surrounded by an ice-water slurry. Disruption was effected by means of the $13 \mathrm{~mm}$. probe of the Dawe Soniprobe (type 1130A; Dawe Instruments Ltd., London, W. 3). The instrument was always used at setting 8 , which gave a current of 4-5 A. The total time of treatment was $15 \mathrm{~min}$., but the current was switched off during every alternate minute to aid cooling, thus giving $8 \mathrm{~min}$. actual disruption. The temperature of the extract never rose above $10^{\circ}$. The homogenate was centrifuged at $20000 \mathrm{~g}$ for $40 \mathrm{~min}$. at $4^{\circ}$; the light-yellow supernatant solution was decanted and used immediately or stored at $-10^{\circ}$.

Enzyme assays. No single medium was found to be suitable for the extraction of optimum amounts of all the enzymes. The following media were used for suspending the cells for disruption and subsequent dilution: L-mandelate dehydrogenase, benzyl alcohol dehydrogenase (Fewson, 1966) and 2-hydroxybenzoate hydroxylase, 0.08 M-sodium pyrophosphate buffer, $\mathrm{pH} 8 \cdot 5$; benzaldehyde dehydrogenase (benzaldehyde-NAD oxidoreductase, formerly EC 1.2.1.6), $0.08 \mathrm{M}$-sodium pyrophosphate buffer, pH9.5; benzoylformate decarboxylase (benzoylformate carboxy-lyase, EC 4.1.1.7), 0.08 M-sodium pyrophosphate buffer, $\mathrm{pH} 7.0$; 4-hydroxybenzoate hydroxylase, 0.05 M-potassium phosphate buffer, pH 7.0; catechol 1,2-oxygenase (EC 1.13.1.1, formerly EC 1.99.2.2), catechol 2,3-oxygenase (EC 1.13.1.2) and 3,4-dihydroxybenzoate oxygenase (protocatechuate dehydrogenase, EC 1.13.1.3, formerly EC 1.99.2.3), $20 \mathrm{~mm}$ tris-HCl buffer containing $10 \mu \mathrm{M}$-disodium EDTA, pH8.0.

Spectrophotometric assays were conducted in $1 \mathrm{~cm}$.-pathlength silica cuvettes containing a total liquid volume of $3.0 \mathrm{ml}$. Measurements of extinction were made with a Unicam SP.800 spectrophotometer that was connected to a Servoscribe chart recorder (Kelvin Electronics Co., Wembley, Middx.). All reactions were carried out at room temperature (approx. $24^{\circ}$ ). Reactions were normally initiated by addition of substrate and reference cuvettes contained water.

L-Mandelate dehydrogenase was measured by a modification of the method of Hegeman (1966a). Reaction mixtures contained: $0.5 \mathrm{ml}$. of $0.1 \mathrm{M}$-sodium pyrophosphate buffer, pH 7.0; $0.1 \mathrm{ml}$. of $2 \mathrm{mM}-2,6$-dichlorophenol-indophenol; $0 \cdot 1 \mathrm{ml}$. of $30 \mathrm{~mm}$-DL-mandelic acid; enzyme; water to a total volume of $3.0 \mathrm{ml}$. The rate of formation of leuco-dye was measured at $600 \mathrm{~m} \mu$. The extinction coefficient of the dye under the assay conditions is $20.6 \times 10^{6} \mathrm{~cm} .{ }^{2} \mathrm{~mole}^{-1}$, and thus a decrease of $6.87 E_{600}$ units corresponded to the oxidation of $1 \mu$ mole of $\mathrm{L}$-mandelate.

Benzoylformate decarboxylase was measured by three different methods. The direct assay measured the rate of disappearance of benzoylformate (Hegeman, 1966a). This procedure has the advantage that it is carried out near the apparent $\mathrm{pH}$ optimum of the enzyme, but it is relatively insensitive. Thiamine pyrophosphate was always included since it approximately doubled the rate even with the crude extract. The reaction mixture contained: $1.0 \mathrm{ml}$. of $0.1 \mathrm{M}$ potassium phosphate buffer, $\mathrm{pH6} \cdot 0 ; 0.1 \mathrm{ml}$. of thiamine pyrophosphate chloride $(500 \mu \mathrm{g} . / \mathrm{ml}$. dissolved in $0.1 \mathrm{M}$ potassium phosphate buffer, $\mathrm{pH} 7.0) ; 0.1 \mathrm{ml}$. of $0.25 \mathrm{M}$ benzoylformic acid; enzyme; water to a total volume of $3.0 \mathrm{ml}$. The rate of disappearance of benzoylformate was measured at $334 \mathrm{~m} \mu$ where, under these conditions, it has an extinction coefficient of $8.1 \times 10^{4} \mathrm{~cm} .{ }^{2} \mathrm{~mole}^{-1}$, so that a decrease of $0.0272 E_{334}$ unit corresponded to the decarb. oxylation of $1 \mu$ mole of benzoylformate. 
A more sensitive assay was devised by coupling the formation of benzaldehyde to the reduction of $\mathrm{NAD}^{+}$with an excess of benzaldehyde dehydrogenase. The reaction mixture contained: $0.5 \mathrm{ml}$. of $0.1 \mathrm{M}$-sodium pyrophosphate buffer, pH 9.5; $0 \cdot 1 \mathrm{ml}$. of an extract of cells grown on benzyl alcohol (equivalent to approx. $1 \mathrm{mg}$. of protein); $0.1 \mathrm{ml}$. of thiamine pyrophosphate chloride $(500 \mu \mathrm{g} . / \mathrm{ml}$. dissolved in $0 \cdot 1 \mathrm{M}$-potassium phosphate buffer, $\mathrm{pH} 7 \cdot 0) ; 0.1 \mathrm{ml}$. of $25 \mathrm{~mm}$ benzoylformic acid; $0.1 \mathrm{ml}$. of $15 \mathrm{~mm}-\mathrm{NAD}^{+}$dissolved in $0.05 \mathrm{M}$-sodium pyrophosphate buffer, $\mathrm{pH} 7.0$; enzyme; water to a total volume of $3.0 \mathrm{ml}$. The appearance of NADH was measured at $340 \mathrm{~m} \mu$. Under the conditions of the assay the extinction change due to disappearance of benzoylformate was insignificant in proportion to the increase in extinction due to NADH formation: an increase of $2.07 E_{340}$ units corresponded to the decarboxylation of $1 \mu \mathrm{mole}$ of benzoylformate.

Neither of the first two methods could be used to measure the decarboxylase activity with 2-hydroxybenzoylformate as substrate because this compound has a high extinction at $340 \mathrm{~m} \mu$ that is about the same as that of the product, 2-hydroxybenzaldehyde, which in turn has a high $K_{m}$ as a substrate for benzaldehyde dehydrogenase. The decarboxylation was accordingly measured in the Warburg apparatus by a modification of the technique of Gunsalus, Stanier \& Gunsalus (1953). Each $15 \mathrm{ml}$. vessel contained: enzyme; $0.1 \mathrm{ml}$. of thiamine pyrophosphate chloride $(500 \mu \mathrm{g} . / \mathrm{ml}$. dissolved in $0.1 \mathrm{M}$-potassium phosphate buffer, $\mathrm{pH} \mathrm{7.0)}$; the reaction was started by tipping from the side arm $0.5 \mathrm{ml}$. of $7.2 \mathrm{~mm}$-substrate that had been adjusted to $\mathrm{pH} 7 \cdot 0$ with $0 \cdot 1 \mathrm{~N}-\mathrm{NaOH}$. The total liquid volume was $2.0 \mathrm{ml}$. and the reaction was run in air at $30^{\circ}$.

Benzyl alcohol dehydrogenase was measured in a reaction mixture containing: $0.5 \mathrm{ml}$. of $0.1 \mathrm{M}$-sodium pyrophosphate buffer, pH 8.5; $0.1 \mathrm{ml}$. of $15 \mathrm{~mm}-\mathrm{NAD}^{+}$(dissolved in $0.05 \mathrm{M}$ sodium pyrophosphate buffer, $\mathrm{pH} 8.5$ ); enzyme; $0.1 \mathrm{ml}$. of $3 \mathrm{~mm}$-benzyl alcohol; water to a total volume of $3.0 \mathrm{ml}$. With a value of $6 \cdot 22 \times 10^{6} \mathrm{~cm} .{ }^{2}$ mole-1 for the extinction coefficient of NADH, an increase of $2.07 E_{340}$ units corresponded to the oxidation of $1 \mu$ mole of benzyl alcohol. A number of substituted aromatic aldehydes, unlike the corresponding alcohols or acids, absorb light at $340 \mathrm{~m} \mu$. The extinction coefficients were found to be $\left(\mathrm{cm} .{ }^{2} \mathrm{~mole}^{-1}\right)$ : 2 - hydroxybenzaldehyde, $1.4 \times 10^{6} ; 3$ - hydroxybenzalde hyde, $1.6 \times 10^{6} ; 4$-hydroxybenzaldehyde, $21.0 \times 10^{6} ; 3,4$ dihydroxybenzaldehyde, $20.0 \times 10^{6} ; 4$-hydroxy-3-methoxybenzaldehyde, $22.5 \times 10^{6}$. The changes in $E_{340}$ had therefore to be corrected to give a true value for the rate of formation of NADH. Correction factors used to convert the $E_{340}$ measurements were as follows: 2-hydroxybenzyl alcohol, 0.82 ; 3-hydroxybenzyl alcohol, $0 \cdot 79$; 4-hydroxybenzyl alcohol, 0.23; 4-hydroxy-3-methoxybenzyl alcohol, $0 \cdot 22$. No correction was made for any benzaldehyde dehydrogenase activity present under these conditions.

Benzaldehyde dehydrogenase was measured by a modification of the method of Gunsalus et al. (1953). Reaction mixtures contained: $0.5 \mathrm{ml}$. of $0.1 \mathrm{M}$-sodium pyrophosphate buffer, pH9.5; $0.1 \mathrm{ml}$. of $15 \mathrm{~mm}-\mathrm{NAD}^{+}($dissolved in $0.05 \mathrm{M}$ sodium pyrophosphate buffer, $\mathrm{pH} 9.5$ ); enzyme; $0.1 \mathrm{ml}$. of $3 \mathrm{~mm}$-benzaldehyde; water to a total volume of $3.0 \mathrm{ml}$. An increase of $2.07 E_{340}$ units corresponded to the oxidation of $1 \mu$ mole of benzaldehyde, but this value was subject to the following correction factors when substituted benzaldehydes were used as substrates: 2-hydroxybenzaldehyde, 1.29; 3-hydroxybenzaldehyde, 1.35; 4-hydroxybenzaldehyde, $-0 \cdot 42 ; 3,4$-dihydroxybenzaldehyde, $-0.46 ; 4$-hydroxy-3methoxybenzaldehyde, $-0 \cdot 38$.

Benzoate oxidase and 4-hydroxy-3-methoxybenzoate $O$-demethylase, the only two enzymes not to be measured in cell-free extracts, were assayed by measuring the rates of oxygen uptake when washed-cell suspensions were incubated with the appropriate substrates. Oxygen uptakes were measured by conventional manometric techniques. Each $15 \mathrm{ml}$. vessel contained: $0.1 \mathrm{ml}$. of $0.3 \mathrm{M}-\left(\mathrm{NH}_{4}\right)_{2} \mathrm{SO}_{4}$; $0.1 \mathrm{ml}$. of $0.03 \mathrm{M}-\mathrm{MgSO}_{4} ; 0.1 \mathrm{ml}$. of $0.5 \mathrm{M}$-potassium phosphate buffer, pH $7.0 ; 0.8 \mathrm{ml}$. of aqueous cell suspension (10 mg. wet wt./ml.). The reaction was initiated by tipping $0.5 \mathrm{ml}$. of $7.2 \mathrm{~mm}$-substrate (dissolved in $0.1 \mathrm{M}$-potassium phosphate buffer and the $\mathrm{pH}$ adjusted to 7.0 with $0.1 \mathrm{~N}$ $\mathrm{NaOH}$ ) from the side arm. The centre well contained $0.2 \mathrm{ml}$. of $20 \%(w / v) \mathrm{KOH}$ and pleated filter paper (Whatman no. 52). The total liquid volume was $2.0 \mathrm{ml}$. The reaction was run in air at $30^{\circ}$. Preliminary experiments showed that the rate of oxygen uptake was proportional to amount of cells up to at least the concentration used. The activities of the enzymes were calculated by assuming that they were rate-limiting in the overall oxygen uptake.

4-Hydroxybenzoate hydroxylase was measured by following the rate of oxidation of NADPH by the method of Hosokawa \& Stanier (1966). FAD was included since it stimulated the rate of hydroxylation even in the crude extracts.

2-Hydroxybenzoate hydroxylase was followed by the technique of Yamamoto, Katagiri, Maeno \& Hayaishi (1965), except that FAD was omitted since it had no beneficial effect on the rate of $\mathrm{NADH}$ oxidation.

Catechol 1,2-oxygenase was assayed by the method of Hegeman (1966a) in which cis-cis-muconate accumulates in the presence of EDTA.

Catechol 2,3-oxygenase activity was measured by the technique of Kojima, Itada \& Hayaishi (1961).

3,4-Dihydroxybenzoate oxygenase was measured by the procedure described by Stanier \& Ingraham (1954).

NADH oxidase was assayed by following the rate of oxidation of $\mathrm{NADH}$ at $340 \mathrm{~m} \mu$ in a reaction mixture that contained: $0.5 \mathrm{ml}$. of $0.1 \mathrm{M}$-sodium pyrophosphate buffer, pH7.0; $0.1 \mathrm{ml}$. of $5 \mathrm{~mm}-\mathrm{NADH}$ (dissolved in $0.05 \mathrm{M}$ sodium pyrophosphate buffer, $\mathrm{pH} 7 \cdot 0$ ); enzyme; water to a total volume of $3.0 \mathrm{ml}$.

Enzyme units are defined as $m \mu$ moles of substrate metabolized/min.; specific activities are the units of enzyme/mg. of protein. All activities were derived from initial rates under conditions where the amount of product was proportional to the concentration of enzyme and time of incubation.

Analytical methods. Values for wet weight of cells were obtained by centrifuging appropriate volumes of cell suspension in tared centrifuge tubes, washing by resuspension in water and centrifugation. Excess of moisture was removed with tissue paper and the tubes were weighed.

Protein was measured by a modification of the technique of Lowry, Rosebrough, Farr \& Randall (1951). To a 1.5 ml. sample $(10-150 \mu \mathrm{g}$. of protein in $0.66 \mathrm{~N}-\mathrm{NaOH})$ was added $1.5 \mathrm{ml}$. of reagent $A\left[100 \mathrm{ml}\right.$. of $13 \%(\mathrm{w} / \mathrm{v}) \mathrm{Na}_{2} \mathrm{CO}_{3}+3 \mathrm{ml}$. of $4 \%(\mathrm{w} / \mathrm{v})$ sodium potassium tartrate tetrahydrate $+3 \mathrm{ml}$. of $2 \%(\mathrm{w} / \mathrm{v}) \mathrm{CuSO}_{4}, 5 \mathrm{H}_{2} \mathrm{O}$ ] with thorough mixing. After $10 \mathrm{~min} .0 .5 \mathrm{ml}$. of Folin-Ciocalteu reagent was added and the solution mixed immediately. The $E_{625}$ value was read after 
a further $30 \mathrm{~min}$. incubation. Bovine serum albumin fraction V (Armour Pharmaceutical Co. Ltd., Eastbourne, Sussex) was used as standard. The protein content of whole cells was determined after solubilization by standing at $30^{\circ}$ in $0.66 \mathrm{~N}-\mathrm{NaOH}$ for $24 \mathrm{hr}$.

Glassware. All glassware used for the growth of bacteria was washed for $15 \mathrm{~min}$. in boiling $10 \%(\mathrm{v} / \mathrm{v}) \mathrm{HNO}_{3}$ and then thoroughly rinsed in glass-distilled water.

Materials. Dr R. Howe (Biochemical Research Department, Pharmaceuticals Division, Imperial Chemical Industries Ltd., Alderley Park, Cheshire) generously synthesized and supplied the 2-hydroxy-DL-mandelic acid and 2-hydroxybenzoylformic acid. DL-Mandelic acid, benzyl alcohol, benzaldehyde (A.R.), benzoic acid (A.R.), 2 hydroxybenzyl alcohol (saligenin), 2-hydroxybenzaldehyde (salicylaldehyde), 2-hydroxybenzoic acid (salicylic acid, A.R.), 3-hydroxybenzaldehyde, 4-hydroxybenzaldehyde, 4-hydroxybenzoic acid, 3,4-dihydroxybenzoic acid (protocatechuic acid), 4-hydroxy-3-methoxy-DL-mandelic acid, 4-hydroxy-3-methoxybenzaldehyde (vanillin, A.R.) and 2,6-dichlorophenol-indophenol were obtained from British Drug Houses Ltd. (Poole, Dorset). 4-Hydroxy-DL-mandelic acid (pure) was from Koch-Light Laboratories Ltd. (Colnbrook, Bucks.). 3-Hydroxybenzyl alcohol and 4-hydroxybenzyl alcohol were purchased from $\mathrm{K} \& \mathrm{~K}$ Laboratories (Plainview, N.Y., U.S.A.). 3-Hydroxy-DL-mandelic acid (purum), 4-hydroxy-3-methoxybenzoic acid (purum) and 4-hydroxy-3-methoxybenzyl alcohol (purum) were purchased from Fluka A.-G. (Buchs, Switzerland). 3,4-Dihydroxy-DL-mandelic acid was supplied by Calbiochem (Los Angeles, Calif., U.S.A.), benzioylformic acid by Aldrich Chemical Co. Inc: (Milwaukee, Wis., U.S.A.) and 3,4-dihydroxybenzaldehyde by Hopkin and Williams Ltd. (Chadwell Heath, Essex). $\mathbf{L}(+)$-Mandelic acid, $\mathrm{D}(-)$-mandelic acid, $\mathrm{NAD}^{+}$, $\mathrm{NADP}^{+}, \mathrm{NADH}, \mathrm{NADPH}, \mathrm{FAD}$ and thiamine pyrophosphate chloride (co-carboxylase) were bought from Sigma (London) Chemical Co. (London, S.W. 6). All other chemicals were the best grade that could be obtained commercially.

Mandelic acid, benzoylformic acid, 2-hydroxybenzyl alcohol, 4-hydroxybenzaldehyde, 4-hydroxybenzoic acid and 3,4-dihydroxybenzoic acid were recrystallized from hot water until the melting points were within a $2^{\circ}$ range that included the literature value. Benzaldehyde, 2-hydroxy- benzaldehyde and benzyl alcohol were redistilled before use: the redistilled benzaldehyde was stored under nitrogen. The optical rotation of the isomers of mandelic acid agreed with the values given in the literature (Mislow, 1951).

All solutions were prepared with glass-distilled water.

\section{RESULTS}

Optimum cell-free assay procedures for the enzymes of the mandelate pathway were developed after initial problems of extraction had been overcome (see the Methods and Materials section). Generally the best $\mathrm{pH}$ for extraction of each enzyme was close to the $\mathrm{pH}$ optimum of activity. Early difficulties with sigmoidal time-courses for benzaldehyde dehydrogenase were found to be due to a dismutation reaction caused by the presence of benzyl alcohol dehydrogenase in extracts prepared at $\mathrm{pH}$ values below 9 . Benzyl alcohol dehydrogenase (pH optimum 8.5) and benzaldehyde dehydrogenase (pH optimum 9.5) were coupled to $\mathrm{NAD}^{+}$reduction, but the NADH oxidase, with a $\mathrm{pH}$ optimum about $\mathbf{7 \cdot 0}$, did not lead to significant errors at the higher $\mathrm{pH}$ values at which these two enzymes were assayed. No NADP+-linked benzaldehyde dehydrogenase was ever detected. L-Mandelate dehydrogenase (pH optimum $\mathbf{7 \cdot 0}$, with a shoulder up to about pH 8.5) was inactive with $\mathrm{NAD}^{+}$or $\mathrm{NADP}^{+}$as electron acceptor, and benzyl alcohol dehydrogenase and benzaldehyde dehydrogenase had no activity with 2,6-dichlorophenol-indophenol. The enzymes were normally assayed after the cell homogenates had been centrifuged at $20000 \mathrm{~g}$ for $40 \mathrm{~min}$. Additional experiments showed that after centrifugation at $140000 \mathrm{~g}$ for $2 \frac{1}{2} \mathrm{hr}$. the benzoylformate decarboxylase, benzyl alcohol dehydrogenase and benzaldehyde dehydrogenase remained entirely in the soluble fraction, whereas $63 \%$ of the L-mandelate dehydrogenase activity and $89 \%$ of the NADH oxidase were in the precipitate. That L-mandelate dehydrogenase may be associated with particles or,

Table 1. Effect of different growth substrates on the activity of the mandelate enzymes in cell-free extracts of bacterium N.C.I.B. 8250

Bacterium N.C.I.B. 8250 was grown on each of the compounds listed, harvested, washed and disrupted as described in the Methods and Materials section. The homogenates were centrifuged at $20000 \mathrm{~g}$ for $40 \mathrm{~min}$. and the specific activities of the enzymes determined in the supernatant solutions. Benzoylformate decarboxylase was measured by both the direct and the coupled reactions.

Enzyme activity ( $\mathrm{m} \mu$ moles/min./mg. of protein)

Growth substrate

DL-Mandelate

Benzoylformate

Benzyl alcohol

Benzaldehyde

Benzoate
Benzoylformate $\underbrace{}_{\text {Benzyl alcohol }}$

$\begin{array}{llll}\begin{array}{c}\text { L-Mandelate } \\ \text { dehydrogenase }\end{array} & \begin{array}{c}\text { Benzoylformate } \\ \text { decarboxylase }\end{array} & \begin{array}{c}\text { Benzyl alcohol } \\ \text { dehydrogenase }\end{array} & \begin{array}{c}\text { Benzaldehyde } \\ \text { dehydrogenase }\end{array}\end{array}$

237

340

$<1$

$<1$
$<1$

$<1$
210

300

$<1$

$<1$

$<1$
95
100
169
202
$<1$
60

213

327 
Table 2. Effect of different growth substrates on the activity of the benzoate-metabolizing and ring-cleavage enzymes in cell-free extracts of bacterium N.C.I.B. 8250

Bacterium N.C.I.B. 8250 was grown on each of the compounds listed, harvested, washed and disrupted as described in the Methods and Materials section. The homogenates were centrifuged at $20000 \mathrm{~g}$ for $40 \mathrm{~min}$. and the speciflc activities of the supernatant solutions determined. Benzoate oxidase and 4-hydroxy-3-methoxybenzoate $O$-demethylase were measured by following the rate of $\mathrm{O}_{2}$ uptake with whole cells (see the Methods and Materials section).

Enzyme activity (m $\mu$ moles/min./mg. of protein)

\begin{tabular}{|c|c|c|c|c|c|c|}
\hline $\begin{array}{c}\text { Benzoate } \\
\text { oxidase }\end{array}$ & $\begin{array}{c}2-\text { Hydroxy- } \\
\text { benzoate } \\
\text { hydroxylase }\end{array}$ & $\begin{array}{c}\text { 4-Hydroxy- } \\
\text { benzoate } \\
\text { hydroxylase }\end{array}$ & $\begin{array}{c}\text { 4-Hydroxy- } \\
\text { 3-methoxy- } \\
\text { benzoate } \\
\text { O-demethylase }\end{array}$ & $\begin{array}{c}\text { Catechol } \\
\text { 1,2- } \\
\text { oxygenase }\end{array}$ & $\begin{array}{c}\text { Catechol } \\
2,3- \\
\text { oxygenase }\end{array}$ & $\begin{array}{c}\text { 3,4-Dihydroxy- } \\
\text { benzoate } \\
\text { oxygenase }\end{array}$ \\
\hline 69 & $<0.5$ & $<0.5$ & $<1$ & 1505 & $<0.1$ & 33 \\
\hline 65 & 86 & $<0.5$ & $<1$ & 944 & $<0.1$ & 31 \\
\hline$<1$ & $<0.5$ & 55 & $<1$ & 5 & $<0.1$ & 3760 \\
\hline$<1$ & $<0.5$ & $<0.5$ & $<1$ & 18 & $<0.1$ & 2510 \\
\hline$<1$ & $<0.5$ & $<0.5$ & 70 & 23 & $<0.1$ & 3115 \\
\hline$<1$ & $<0.5$ & $<0.5$ & $<1$ & $<1$ & $<0.1$ & $<1$ \\
\hline
\end{tabular}

more likely, membranes was also indicated by the fact that longer ultrasonic treatment was required to release maximum amounts of this enzyme into the $20000 \mathrm{~g}$ supernatant fraction than was required to release 'total' protein or the other enzymes.

Table 1 shows that L-mandelate dehydrogenase, benzoylformate decarboxylase, benzyl alcohol dehydrogenase and benzaldehyde dehydrogenase were all induced by growth on mandelate or benzoylformate. Only benzyl alcohol dehydrogenase and benzaldehyde dehydrogenase were present in cells grown on benzyl alcohol or benzaldehyde. None of the enzymes was induced by benzoate. The upper limits of the enzyme activities for cells grown on benzoate represent the smallest amounts that could have been detected under the routine assay con. ditions. The activities may well have been much less than this, but no attempt was made to evaluate the non-induced enzyme activities.

The specificity of induction of the benzoatemetabolizing and ring-cleavage enzymes is illustrated in Table 2. Benzoate oxidase was detected in cells grown on benzoate or on 2-hydroxybenzoate. 2 - Hydroxybenzoate hydroxylase, 4 - hydroxy benzoate hydroxylase and 4-hydroxy-3-methoxybenzoate $O$-demethylase were induced only by growth on the homologous substrates. Catechol 1,2-oxygenase was found after growth on benzoate or 2-hydroxybenzoate, and 3,4-dihydroxybenzoate oxygenase was induced by growth on the other substituted benzoates. The small amounts of activity of 3,4-dihydroxybenzoate oxygenase in extracts with catechol 1,2-oxygenase, and of catechol 1,2-oxygenase in extracts with 3,4-dihydroxybenzoate oxygenase, may represent slight non-specificity either of induction or of activity. No catechol 2,3-oxygenase activity was ever detected in bacterium N.C.I.B. 8250, though the assay procedure worked satisfactorily with extracts prepared from organisms B 9, $\beta 8$ and M 2 .
The specificities of the enzymes of the mandelateto-benzoate pathway were tested by determining the maximum velocity, $V$, and Michaelis constant, $K_{m}$, for a number of substrates. Identity of these values for enzymes prepared from cells grown on a number of carbon sources was taken to be at least a first indication that the same enzyme was induced in each case. A few substrates (e.g. 2-hydroxy-DLmandelate, benzyl alcohol) showed quite pronounced substrate inhibition when tested at sufficiently high concentrations, but this did not significantly interfere with the determination of $V$ and $K_{m}$.

The enzyme constants for L-mandelate dehydrogenase (Table 3) were the same regardless of the growth substrate. The reproducibility of the results was tested by growing seven separate batches of cells on DL-mandelate and determining the $K_{m}$ for DL-mandelate: the mean was 235 (s.e.M. $\pm 2 \cdot 4) \times 10^{-6} \mathrm{M}$. The results in Table 3 show that the substrate for the enzyme is the $\mathrm{L}$-isomer. There was no activity with $\mathrm{D}$-mandelate, so that it is unlikely that mandelate racemase (EC 5.1.2.2) was present: this agrees with the fact that bacterium N.C.I.B. 8250 grows on L-mandelate but not on D-mandelate (Fewson, 1967a). The stoicheiometry of oxidation of the substituted mandelates showed that in each case only the L-isomer was oxidized.

Benzoylformate decarboxylase activity was detected in cells grown on DL-mandelate, 2-hydroxyDL - mandelate, 4 - hydroxy - DL - mandelate, 3,4 dihydroxy-DL-mandelate, 4-hydroxy -3-methoxy DL-mandelate, benzoylformate and 2-hydroxy benzoylformate. Only two substrates for this enzyme were available, but in all the cases tested the maximum velocity with 2-hydroxybenzoylformate was $6 \%$ of that with benzoylformate.

Benzyl alcohol dehydrogenase also showed the same substrate specificity regardless of the carbon source for growth (Table 4). 
Table 3. Specificity of mandelate oxidation by cell-free extracts of bacterium N.C.I.B. 8250 prepared from cells grown on a number of substrates

Bacterium N.C.I.B. 8250 was grown on each compound in turn, harvested, washed and disrupted as described in the Methods and Materials section. The homogenates were centrifuged at $20000 \mathrm{~g}$ for $40 \mathrm{~min}$. and the supernatant solutions used as the source of enzyme. Reaction mixtures contained: sodium pyrophosphate buffer, pH 7.0, 50 $\mu$ moles; 2,6-dichlorophenol-indophenol, $200 \mathrm{~m} \mu$ moles; a mandelate at the appropriate concentration; extract; water to a total volume of 3.0 ml. The values for $V$ and $\boldsymbol{K}_{m}$ were determined from Lineweaver \& Burk (1934) plots. - Not determined.

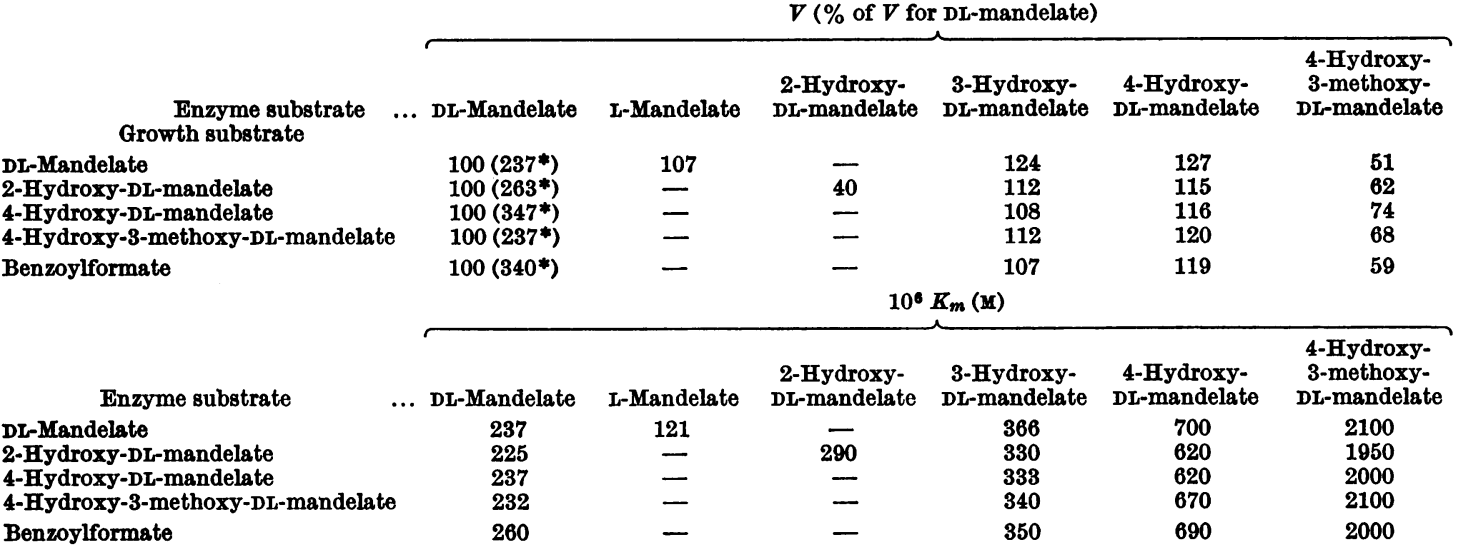

* Values in parentheses represent the actual values for $V$ with DL-mandelate as substrate, expressed as $\mathrm{m} \mu \mathrm{moles}$ oxidized/min./mg. of protein.

Table 4. Specificity of benzyl alcohol oxidation by cell-free extracts of bacterium N.C.I.B. 8250 prepared from cells grown on a number of substrates

Bacterium N.C.I.B. 8250 was grown on each compound in turn, harvested, washed and disrupted as described in the Methods and Materials section. The homogenates were centrifuged at $20000 \mathrm{~g}$ for $40 \mathrm{~min}$. and the supernatant solutions used as the source of enzyme. Reaction mixtures contained: sodium pyrophosphate buffer, $\mathrm{pH} 8 \cdot 5$, $50 \mu$ moles; $\mathrm{NAD}^{+}, 1 \cdot 5 \mu$ moles; a benzyl alcohol at the appropriate concentration; extract; water to a total volume of 3.0ml. The values for $V$ and $K_{m}$ were determined from Lineweaver \& Burk (1934) plots.

$V$ (\% of $V$ for benzyl alcohol)

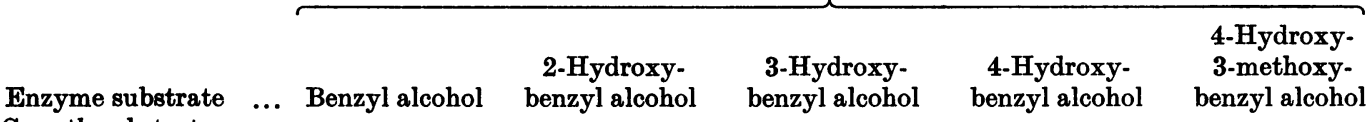

DL-Mandelate

4-Hydroxy-DL-mandelate

$100\left(95^{*}\right) \quad 67$

$100\left(75^{*}\right)$

$100\left(169^{*}\right)$

$100\left(198^{*}\right)$

$100\left(440^{*}\right)$

$100\left(202^{*}\right)$
69

63

57

57

64
66

61

59

55

53

57
44

32

37

32

29

36
42

35

35

32

30

35

Benzaldehyde

$10^{6} K_{m}(\mathrm{M})$

Enzyme substrate $\quad \ldots$ Benzyl alcohol $\begin{gathered}\text { 2-Hydroxy- } \\ \text { benzyl alcohol }\end{gathered}$

DL-Mandelate

4-Hydroxy-DL-mandelate

Benzyl alcohol

2-Hydroxybenzyl alcohol

4-Hydroxybenzyl alcohol

Benzaldehyde

$\begin{array}{ll}11 & 68 \\ 11 & 69 \\ 12 & 63 \\ 12 & 66 \\ 12 & 65 \\ 11 & 60\end{array}$

69

63

66

60
3-Hydroxy-

benzyl alcohol
4-Hydroxy-

4-Hydroxy3-methoxy-

46

54

46

50

49

46 benzyl alcohol

$\begin{array}{ll}44 & 44 \\ 39 & 36 \\ 40 & 35 \\ 43 & 39 \\ 39 & 40 \\ 42 & 34\end{array}$

* Values in parentheses represent the actual values for $V$ with benzyl alcohol as substrate, expressed as $\mathrm{m} \mu \mathrm{moles}$ oxidized/min./mg. of protein. 
Table 5. Specificity of benzaldehyde oxidation by cell-free extracts of bacterium N.C.I.B. 8250 prepared from cells grown on a number of substrates

Bacterium N.C.I.B. 8250 was grown on each compound in turn, harvested, washed and disrupted as described in the Methods and Materials section. The homogenates were centrifuged at $20000 \mathrm{~g}$ for $40 \mathrm{~min}$. and the supernatant solutions used as the source of enzyme. Reaction mixtures contained: sodium pyrophosphate buffer, pH $9.5,50 \mu$ moles; $\mathrm{NAD}^{+}, 1.5 \mu \mathrm{moles} ;$ the appropriate benzaldehyde, $120 \mathrm{~m} \mu$ moles; extract; water to a total volume of $3.0 \mathrm{ml}$.

Velocity (\% of that obtained with benzaldehyde)

\begin{tabular}{|c|c|c|c|c|c|c|}
\hline & & & & & & \\
\hline $\begin{array}{l}\text { Enzyme substrate } \quad \ldots \quad \text {. } \\
\text { Growth substrate }\end{array}$ & .. Benzaldehyde & $\begin{array}{l}\text { 2-Hydroxy- } \\
\text { benzaldehyde }\end{array}$ & $\begin{array}{l}\text { 3-Hydroxy- } \\
\text { benzaldehyde }\end{array}$ & $\begin{array}{l}\text { 4-Hydroxy- } \\
\text { benzaldehyde }\end{array}$ & $\begin{array}{l}\text { 3,4-Dihydroxy- } \\
\text { benzaldehyde }\end{array}$ & $\begin{array}{l}\text { 4-Hydroxy-8- } \\
\text { methoxy- } \\
\text { benzaldehyde }\end{array}$ \\
\hline $\begin{array}{l}\text { DI-Mandelate } \\
\text { 4-Hydroxy-DI-mandelate } \\
\text { 4-Hydroxy-3-methoxy-DI-mandelate }\end{array}$ & $\begin{array}{l}100\left(60^{*}\right) \\
100\left(118^{*}\right) \\
100\left(73^{*}\right)\end{array}$ & $\begin{array}{l}7 \\
8 \\
7\end{array}$ & $\begin{array}{l}72 \\
72 \\
70\end{array}$ & $\begin{array}{l}52 \\
47 \\
48\end{array}$ & $\begin{array}{l}10 \\
16 \\
12\end{array}$ & $\begin{array}{l}6 \\
8 \\
5\end{array}$ \\
\hline $\begin{array}{l}\text { Benzyl alcohol } \\
\text { 2-Hydroxybenzyl alcohol } \\
\text { 4-Hydroxybenzyl alcohol }\end{array}$ & $\begin{array}{l}100\left(113^{*}\right) \\
100\left(123^{\star}\right) \\
100\left(467^{\star}\right)\end{array}$ & $\begin{array}{l}9 \\
6 \\
6\end{array}$ & $\begin{array}{l}68 \\
65 \\
63\end{array}$ & $\begin{array}{l}40 \\
39 \\
38\end{array}$ & $\begin{array}{l}\mathbf{8} \\
\mathbf{8} \\
\mathbf{9}\end{array}$ & $\begin{array}{l}5 \\
4 \\
4\end{array}$ \\
\hline $\begin{array}{l}\text { Benzaldehyde } \\
\text { 4-Hydroxy-8-methoxybenzaldehyde }\end{array}$ & $\begin{array}{l}100(327 *) \\
100(104 *)\end{array}$ & $\begin{array}{l}6 \\
6\end{array}$ & $\begin{array}{l}68 \\
69\end{array}$ & $\begin{array}{l}40 \\
42\end{array}$ & $\begin{array}{l}8 \\
9\end{array}$ & $\begin{array}{l}4 \\
5\end{array}$ \\
\hline
\end{tabular}

*Values in parentheses represent the actual values for the velocity with benzaldehyde as substrate, expressed as m $\mu$ moles oxidized/min./mg. of protein.

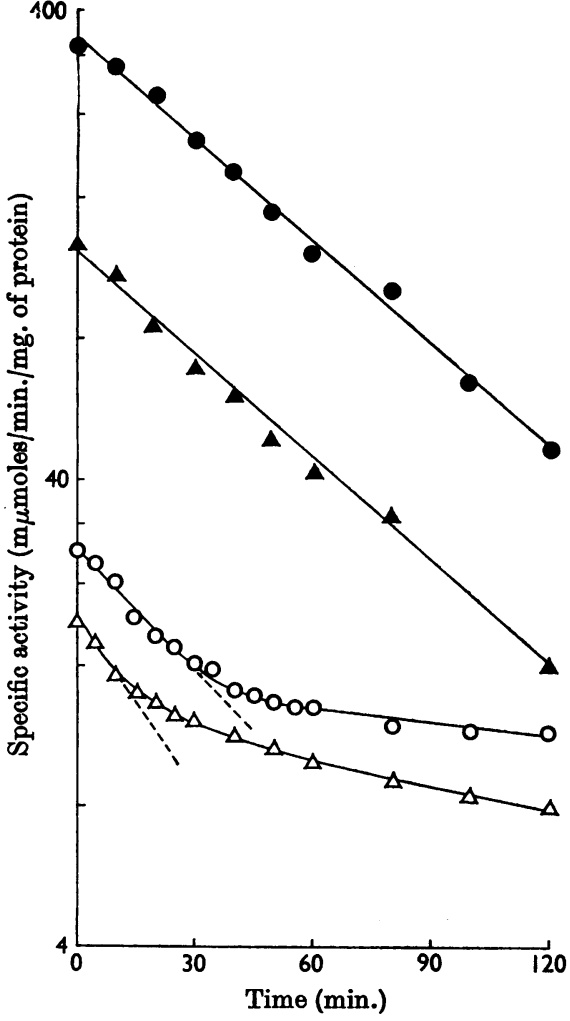

Fig. 1. Heat inactivation of benzaldehyde dehydrogenase of bacterium N.C.I.B. 8250. Cells were grown on mandelate (O), benzoylformate $(\Delta)$, benzylalcohol $(\bullet)$ or benzaldehyde $(\Delta)$ as sources of carbon and energy, harvested, washed and disrupted. The extracts prepared by centrifugation at $20000 \mathrm{~g}$ for $40 \mathrm{~min}$. were incubated at $37 \cdot 5^{\circ}$ and samples taken at intervals for determination of benzaldehyde dehydrogenase activity as described in the Methods and Materials section.
Table 6. Rates of oxidation of various mandelates when added either singly or in pairs to a cell-free extract of bacterium N.C.I.B. 8250

Bacterium N.C.I.B. 8250 was grown on mandelate as sole carbon source, harvested, washed and disrupted as described in the Methods and Materials section. The homogenate was centrifuged at $20000 \mathrm{~g}$ for $40 \mathrm{~min}$. and the supernatant solution used as the source of enzyme. The reaction mixtures contained sodium pyrophosphate buffer, $\mathrm{pH} 7 \cdot 0,50 \mu$ moles; 2,6-dichlorophenol-indophenol, $200 \mathrm{~m} \mu$ moles; extract equivalent to $230 \mu \mathrm{g}$. of protein; mandelates at the appropriate concentration; water to a total volume of $3.0 \mathrm{ml}$.
Enzyme substrate

DL-Mandelate

DL-Mandelate

4-Hydroxy-DL-mandelate

4-Hydroxy-DL-mandelate

3-Hydroxy-DL-mandelate 3-Hydroxy-DL-mandelate DL-Mandelate+

3-hydroxy-DL-mandelate

4-Hydroxy-DL-mandelate+ 3-hydroxy-DL-mandelate
Enzyme rate

Concn. (m $\mu$ moles/min./ (mM) mg. of protein)

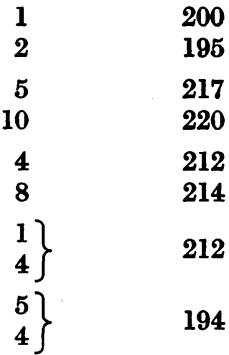

The $K_{m}$ for benzaldehyde as the substrate for benzaldehyde dehydrogenase was less than $6 \times 10^{-6} \mathrm{M}$, but a precise determination could not be made because of the lack of sensitivity of the method used. Further, it was not possible to make accurate determinations of $K_{m}$ and $V$ for some substrates because of their high extinction coefficients. The best comparison of substrate specificity that could be made was by determining the relative velocity with all substrates at $40 \mu \mathrm{M}$ 
(Table 5). The values are subject to more error than the determination of the kinetic constants of the other enzymes, since they were not obtained graphically and were subject to large correction factors caused by the extinctions at $340 \mathrm{~m} \mu$ (see the Methods and Materials section). There is a slight indication that the enzyme of cells grown on mandelate or the substituted mandelates was slightly more active with 4-hydroxybenzaldehyde or 3,4-dihydroxybenzaldehyde as substrate than was the enzyme from cells grown on the benzyl alcohols or benzaldehydes, but it is not clear whether this is really significant. Further experiments were therefore carried out. A clear difference between the enzymes in cells grown on different substrates was revealed when the thermal stability of benzaldehyde dehydrogenase was tested (Fig. 1). Bacterium N.C.I.B. 8250 grown on benzyl alcohol or benzaldehyde contained an enzyme with a half-life of about $35 \mathrm{~min}$. at $37.5^{\circ}$ under the conditions tested. Extracts of cells grown on mandelate or benzoylformate showed a quite different pattern of heat inactivation: there was an initial rapid loss of activity corresponding approximately to the halflife of the enzyme from cells grown on benzyl alcohol, followed by a much slower loss of activity (half-life about $150 \mathrm{~min}$.). It therefore appears that cells grown on benzyl alcohol or benzaldehyde contain a relatively heat-labile benzaldehyde dehydrogenase, whereas cells grown on mandelate or benzoylformate contain approximately equal amounts of the heat-labile enzyme and a second more heat-stable benzaldehyde dehydrogenase. Subsequent work (A. Livingstone \& C. A. Fewson, unpublished results) has shown that the heat-stable enzyme, but not the heat-labile enzyme, is activated by $\mathrm{K}^{+}$ions.

The possibility that mandelate or other compounds might non-specifically induce several substrate-specific enzymes was ruled out by experiments in which combinations of substrates were provided together. In no case was the rate with a pair of substrates more than the higher of the individual rates. Data for this type of experiment with L-mandelate dehydrogenase are given in Table 6, and experiments with benzyl alcohol dehydrogenase and benzaldehyde dehydrogenase gave similar results.

\section{DISCUSSION}

The results reported in this paper support the suggestion (Kennedy \& Fewson, 1966) that bacterium N.C.I.B. 8250 oxidizes L-mandelate, benzyl alcohol and their substituted analogues to the corresponding benzoates by a series of parallel pathways whose enzymes are non-specific in their activity and induction. This is similar to the more restricted situation in Pseudomonas putida, where the same series of enzymes oxidize mandelate and 4-hydroxymandelate to benzoate and 4-hydroxybenzoate respectively (Gunter, 1953; Stanier, Gunsalus \& Gunsalus, 1953; Stevenson \& Mandelstam, 1965). However, the mandelate pathways in the two organisms are not identical, since bacterium N.C.I.B. 8250 does not possess a mandelate racemase (see the Results section) and thus cannot grow on D-mandelate (Fewson, 1967a). The absence of an NADP-linked benzaldehyde dehydrogenase from bacterium N.C.I.B. 8250 also differentiates this system from that in $P$. putida (e.g. Hegeman, $1966 a$ ). The evidence for the identity of the enzymes produced by bacterium N.C.I.B. 8250 during growth on the various substrates rests largely on an examination of the kinetic properties of the enzymes with a number of substrates. This seems good presumptive evidence, but final proof must await further studies such as the purification of the enzymes and preparation of specific antisera. The use of mutants could also be helpful: Stevenson \& Mandelstam (1965) have already shown that a mutant of $P$. putida devoid of L-mandelate dehydrogenase is unable to grow on either mandelate or 4-hydroxymandelate.

The quantitative data on the enzyme activities are of interest since they may help to furnish information about the nature of the enzymes, or could be used in comparative studies with similar enzymes from other species. However, of the enzymes involved in the oxidation of mandelate to benzoate by $P$. putida, the kinetic properties of only the mandelate racemase appear to have been reported in detail (Weil-Malherbe, 1966). It should be borne in mind that a quantitative examination of the specificity of enzyme induction may well show a similar type of dependence on the substitution of the aromatic ring. Differences in growth rates on various compounds (C. A. Fewson, unpublished work) should ultimately be attributable to differences in substrate and induction specificity as well as to other possible factors such as permeation and toxicity. It is noteworthy, for instance, that 4-hydroxy-3-methoxy-DL-mandelate has a lower maximum velocity and higher $K_{m}$ than has DL-mandelate when tested as a substrate for L-mandelate dehydrogenase, and that bacterium N.C.I.B. 8250 grows very much more slowly on the former compound (C. A. Fewson, unpublished work). The results on substrate specificity also show that some compounds that do not support growth, such as the 3-hydroxy-substituted analogues, may serve as substrates for the enzymes.

The enzymes of the mandelate-to-benzoate pathway are induced co-ordinately in $P$. putida (Hegeman, 1966a,b,c). The failure of benzaldehyde to induce L-mandelate dehydrogenase and benzoyl- 
L-Mandelate<smiles>[R12][X]</smiles>

Benzoylformate

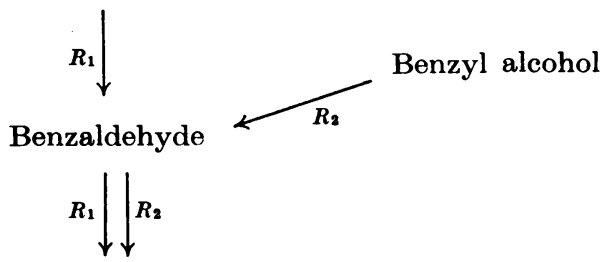

\section{Benzoate}

Scheme 1. Regulation of the pathway for the oxidation of L-mandelate and benzyl alcohol in bacterium N.C.I.B. 8250. $R_{1}$ and $R_{2}$ indicate separate co-ordinate groups of enzymes.

formate decarboxylase in bacterium N.C.I.B. 8250 (Table 1) might at first sight suggest that the regulation of these enzymes is quite different in the two organisms. $P$. putida, in fact, does not appear to have been grown on benzaldehyde, possibly because of difficulties with toxicity and autooxidation, though Stevenson \& Mandelstam (1965) have shown that the addition of benzaldehyde to $P$. putida growing on glucose led to the ability of whole cells to oxidize benzaldehyde, but did not induce L-mandelate dehydrogenase or benzoylformate decarboxylase. It appears likely from the results reported in this paper that, in bacterium N.C.I.B. 8250, benzaldehyde induces a heat-labile benzaldehyde dehydrogenase controlled by a different regulon (the term operon is not applicable since there is no evidence about the relative location of the different genes; see Maas \& McFall, 1964) from that which controls L-mandelate dehydrogenase and benzoylformate decarboxylase. These two enzymes, however, are probably controlled in one co-ordinate group together with the heat-stable benzaldehyde dehydrogenase. This idea is summarized in Scheme 1. L-Mandelate and benzyl alcohol are oxidized to benzoate by a converging pathway whose enzymes are controlled in two co-ordinate groups. The first regulon, $R_{1}$, controls L-mandelate dehydrogenase, benzoylformate decarboxylase and the heat-stable benzaldehyde dehydrogenase. This system is induced by $\mathrm{L}$ mandelate or benzoylformate, or their substituted analogues, but not by benzaldehyde. The second regulon, $R_{2}$, controls benzyl alcohol dehydrogenase and the heat-labile benzaldehyde dehydrogenase. This group is induced by benzyl alcohol, benzaldehyde or their substituted derivatives. $R_{2}$ must also be induced to some extent by L-mandelate or benzoylformate, or be linked in some way to $R_{1}$, because cells grown on L-mandelate or benzoylformate contain appreciable amounts of benzyl alcohol dehydrogenase (Table 1) and the heat-labile benzaldehyde dehydrogenase (Fig. 1). It may well be that a rather similar situation exists in $P$. putida, since Stevenson \& Mandelstam (1965) postulated the existence of 'an additional aldehyde dehydrogenase which was induced by benzaldehyde and subsequently destroyed during preparation of the cell-free extract' so that they were unable to measure it. The existence of two isofunctional benzaldehyde dehydrogenases at the point where the L-mandelate and benzyl alcohol pathways overlap is reminiscent of the isofunctional enzymes that occur in $M$. calcoacetica (strain 73) at the point where the catechol and 3,4-dihydroxybenzoate pathways overlap (Cánovas \& Stanier, 1967).

The data in Table 2 suggest that the benzoatemetabolizing enzymes are controlled by separate and independent regulatory systems. This is not surprising, since these enzymes all carry out reactions centred on the aromatic ring itself. A different enzyme is therefore required for the metabolism of each of the substituted benzoates that can support growth of bacterium N.C.I.B. 8250 .

We are grateful to Professor J. N. Davidson, F.R.S., for making available the facilities of this Department and to Dr W. H. Holms for the use of apparatus purchased with grants from the Science Research Council and the Royal Society. Mrs I. Gall provided skilled technical assistance throughout this work.

\section{REFERENCES}

Cain, R. B. (1961). Biochem. J. 79, 298.

Cánovas, J. L., Ornston, L. N. \& Stanier, R. Y. (1967). Science, 156, 1695.

Cánovas, J. L. \& Stanier, R. Y. (1967). Europ. J. Biochem. 1, 289.

Fewson, C. A. (1966). Biochem. J. 101, 21 P.

Fewson, C. A. (1967a). J. gen. Microbiol. 46, 255.

Fewson, C. A. (1967b). J.gen. Microbiol. 48, 107.

Fewson, C. A. \& Kennedy, S. I. T. (1968). Biochem. J. 106, $31 P$.

Gunsalus, C. F., Stanier, R. Y. \& Gunsalus, I. C. (1953). J. Bact. 66, 548.

Gunter, S. E. (1953). J. Bact. 66, 341.

Harvey, N. L., Fewson, C. A. \& Holms, W. H. (1968). Biochem.J. 106, 57P.

Hegeman, G. D. (1966a). J. Bact. 91, 1140.

Hegeman, G. D. (1966b). J. Bact. 91, 1155.

Hegeman, G. D. (1966c). J. Bact. 91, 1161.

Hosokawa, K. \& Stanier, R. Y. (1966). J. biol. Chem. 241, 2453.

Kennedy, S. I. T. \& Fewson, C. A. (1966). Biochem. J.100, 25 P.

Kojima, Y., Itada, N. \& Hayaishi, O. (1961). J. biol. Chem. 236, 2223. 
Lineweaver, H. \& Burk, D. (1934). J. Amer. chem. Soc. 56, 658.

Lowry, O. H., Rosebrough, N. J., Farr, A. L. \& Randall, R. J. (1951). J. biol. Chem. 193, 265.

Maas, W. \& McFall, E. (1964). Annu. Rev. Microbiol. 18, 95.

Mislow, K. (1951). J. Amer. chem. Soc. 73, 3954.

Ornston, L. N. \& Stanier, R. Y. (1964). Nature, Lond., 204, 1279.

Pankhurst, E. S. (1965). J. appl. Bact. 28, 309.
Sebald, M. \& Véron, M. (1963). Ann. Inst. Pasteur, 105, 897. Stanier, R. Y., Gunsalus, I. C. \& Gunsalus, C. F. (1953). J. Bact. 66, 543.

Stanier, R. Y. \& Ingraham, J. L. (1954). J. biol. Chem. 210, 799.

Stevenson, I. L. \& Mandelstam, J. (1965). Biochem.J.96, 354. Véron, M. (1966). Ann. Inst. Pasteur, 111, 671,

Weil-Malherbe, H. (1966). Biochem. J. 101, 169.

Yamamoto, S., Katagiri, M., Maeno, H. \& Hayaishi, 0. (1965). J. biol. Chem. 240, 3408. 